\title{
Kepemilikan Fasilitas Sanitasi Dasar Rumah Tangga Di Desa Air Selumar Kecamatan Sijuk Kabupaten Belitung
}

\author{
Ownership of Basic Household Sanitation Facilities in Air Selumar Village, Sijuk District, \\ Belitung Regency
}

\author{
Dyah Suryani*, Irma Listari \\ Fakultas Kesehatan Masyarakat, Universitas Ahmad Dahlan, Yogyakarta \\ e-mail:*dyah.suryani@ikm.uad.ac.id
}

\begin{abstract}
Abstrak
Kepemilikan sarana sanitasi dasar rumah merupakan salah satu syarat rumah sehat. Permasalahan kesehatan yang ada di lingkungan rumah tidak lepas dari tingkat pengetahuan, sikap, pendapatan kepala keluarga dan jumlah anggota kepala keluarga. Maka dari itu masih banyak masyarakat yang belum memiliki pemikiran akan pentingnya sanitasi dasar bagi hidupnya dan masih banyak pula masyarakat yang belum memiliki fasilitas sanitasi dasar. Tujuan dari penelitian ini adalah untuk mengetahui faktor-faktor yang berhubungan dengan kepemilikan fasilitas sanitasi dasar rumah tangga di Desa Air Selumar Kecamatan Sijuk Kabupaten Belitung. Penelitian ini menggunakan metode analitik observasional dengan pendekatan cross sectional. Sampel dalam penelitian ini sejumlah 101 sampel, menggunakan Proportional Random Sampling. Instrumen penelitian yaitu kuesioner dan checklist. Analisis data dilakukan dengan menggunakan uji Chi square. Hasil analisis bivariat menunjukkan ada hubungan antara tingkat pengetahuan deng an kepemilikan fasilitas sanitasi dasar rumah tangga $p$ value $=0,000$, ada hubungan antara sikap dengan kepemilikan fasilitas sanitasi dasar rumah tangga $p$ value $=0,005$, ada hubungan antara tingkat pendapatan dengan kepemilikan fasilitas sanitasi dasar rumah tangga $p$ value $=0,000$, ada hubungan antara jumlah anggota keluarga dengan kepemilikan fasilitas sanitasi dasar rumah tangga $p$ value $=0,016$. Tingkat pengetahuan, sikap, tingkat pendapatan dan jumlah anggota keluarga berhubungan dengan kepemilikan fasili tas sanitasi dasar rumah tangga di Desa Air Selumar Kecamatan Sijuk Kabupaten Belitung. .
\end{abstract}

Kata kunci: Pengetahuan, Sikap, Pendapatan, Anggota Keluarga, Sanitasi Dasar, Rumah Tangga.

\begin{abstract}
Ownership of basic sanitation facilities of the house is one of the conditions of a healthy home, can not separate health problems in the home environment from the level of knowledge, attitude, the income of the head of the family and the number of dependents of the head of the family. It is seen that there are still people who do not have thoughts about the importance of basic sanitation for their lives and there are still many people who do not have basic sanitation facilities. This study aims to find out the factors related to the ownership of basic household sanitation facilities in Selumar Water Village, Sijuk Subdistrict, Belitung Regency. This study uses observational analytics method with cross sectional approach. The samples in this study numbered 101 samples, using proportional random sampling method. Research instruments are questionnaires and checklists. Data analysis is performed using Chi square test. Bivariate analysis results show there is a relationship between the level of knowledge and the ownership of basic household sanitation facilities $p$ value $=0.000$, there is a relationship between attitude with the ownership of basic household sanitation facilities $p$ value $=0.005$, there is a relationship between the level of income and the ownership of basic household sanitation facilities $p$ value $=0.000$, there is a relationship between the number of family members and the ownership of basic household sanitation facilities $p$ value $=0.016$. The level of knowledge, attitude, income level, and family members relate to the ownership of basic household sanitation facilities in Selumar Water Village, Sijuk Subdistrict, Belitung Regency.
\end{abstract}

Keywords: Knowledge, Attitude, Income, family members, Basic Sanitation, Household

\section{Pendahuluan}

Sarana sanitasi adalah fasilitas yang dimiliki keluarga dalam rumah tangganya untuk keperluan kegiatan sanitasi. Fasilitas sanitasi dasar meliputi fasilitas air bersih dan air minum, fasilitas jamban keluarga, dan fasilitas pembuangan sampah rumah tangga. Ketersediaan fasilitas harus diikuti dengan pemeliharaan agar manfaat keamanan dan kenyamanan dapat tercapai ${ }^{1}$. Sanitasi, higiene atau akses air yang tidak memadai dapat meningkatkan kejadian penyakit diare yang mengakibatkan kematian sedikitnya 1,9 juta anak balita setiap tahunnya ${ }^{2}$. Bahkan sanitasi dasar dapat juga menjadi indikator 
potensial penyebaran penyakit coronavirus-2019 (COVID-19), dalam konteks ini pola ruang-waktu adalah alat penting untuk menjelaskan penyebaran penyakit dan mengidentifikasi faktor risiko ${ }^{3}$. Sekitar 2,2 miliar orang di seluruh dunia tidak memiliki akses air minum dan 4,2 miliar untuk sanitasi dasar, sebagian besar dari mereka berada di negara-negara terbelakang ${ }^{4}$. Data menunjukkan bahwa 87,8\% rumah tangga di Indonesia memiliki akses ke sumber air minum yang aman, dan 74,6\% rumah tangga memiliki akses terhadap sanitasi yang layak. Sedangkan 25,4\% sisanya tidak memiliki akses sanitasi yang layak ${ }^{5}$. Peningkatan pengelolaan sanitasi rumah tangga dapat dilakukan dengan mengoptimalkan peran sumber daya dalam keluarga, memanfaatkan sumber informasi dan pengetahuan, memberikan motivasi dalam pemberdayaan keluarga, dan menyediakan fasilitas sanitasi penunjang ${ }^{1}$. Kurangnya pengetahuan, sikap, dan praktik (KAP) tentang air bersih, sanitasi, dan kebersihan (WASH) merupakan salah satu penyebab utama penularan penyakit menular ${ }^{6}$.

Menurut data Susenas tahun 2019 secara nasional persentase rumah tangga dengan akses air minum layak sebesar 73,65\%. Provinsi dengan persentase tertinggi rumah tangga dengan akses air minum layak yaitu Kalimantan Timur (93,77\%), Kepulauan Riau $(91,53 \%)$ dan Bali $(88,67 \%)$. Sedangkan provinsi dengan persentase rumah tangga terendah adalah Kalimantan Barat (37,37\%), Papua (39,05\%), dan Bengkulu (49,52\%). Persentase keluarga dengan akses terhadap fasilitas sanitasi yang layak (jamban sehat) di Indonesia pada tahun 2019 adalah 87,81\%. Provinsi dengan persentase tertinggi keluarga dengan akses terhadap fasilitas sanitasi yang layak (jamban sehat) adalah DI Yogyakarta (100\%), Sulawesi Selatan (97,58\%), dan Kepulauan Bangka Belitung (95,57\%). Provinsi dengan persentase terendah adalah Papua $(53,74 \%)$, Kalimantan Barat $(71,81 \%)$, dan Kalimantan Tengah $(73,27 \%)^{7}$.

Menurut data pada tahun 2019 jumlah sarana air minum yang terdata di Kepulauan Bangka Belitung sebanyak 47.987 sarana dan sebanyak 98,93\% yang diinspeksi. Sarana air minum yang memenuhi syarat tertinggi ada di Kabupaten Bangka Selatan dan terendah ada di Kabupaten Belitung Timur. Keluarga dengan akses fasilitas sanitasi layak (jamban sehat) sebesar 95,72\%. Tertinggi di kota Pangkalpinang sebesar 99,84\% dan terendah di Kabupaten Belitung ${ }^{8}$. Data rekapitulasi Dinas Kesehatan Kabupaten Belitung bulan juli tahun 2020 menunjukkan bahwa persentase penduduk dengan akses keberlanjutan terhadap air minum berkualitas layak menurut kecamatan dan puskesmas sebesar 75,48\%. Penduduk dengan akses keberlanjutan terhadap air minum berkualitas layak tertinggi adalah Kecamatan Selat Nasik sebesar 100\%. Sedangkan terendah adalah Kecamatan Sijuk sebesar 57,33\% . Tujuan penelitian ini adalah untuk melihat Faktor-Faktor Yang Berhubungan Dengan Kepemilikan Fasilitas Sanitasi Dasar Rumah Tangga Di Desa Air Selumar Kecamatan Sijuk Kabupaten Belitung.

\section{Metode Penelitian}

Penelitian ini menggunakan dengan metode analitik observasional dengan pendekatan Cross Sectional. Populasi dalam penelitian ini adalah seluruh kepala keluarga yang ada di Desa Air Selumar yaitu terdiri dari 4 Dusun, 18 RT dan 1028 KK. Sampel dalam penelitian ini diambil dengan rumus slovin dan didapat sejumlah 101 sampel. Teknik pengambilan sampel menggunakan cara Proportional Random Sampling. Instrumen penelitian yaitu kuesioner untuk mengukur tingkat pengetahuan, sikap, tingkat pendapatan, jumlah anggota keluarga dan check list untuk melihat kepemilikan fasilitas sanitasi dasar rumah tangga. Kuesioner pengetahuan (benar dan salah) dan sikap (setuju dan tidak setuju) masing-masing terdiri atas 20 pertanyaan. Pertanyaan tersebut berkaitan dengan sarana air bersih, jamban, Sarana Pembuangan Air Limbah (SPAL), dan sarana pembuangan sampah. Kuesioner tersebut sebelumnya diuji validitas dan reliabilitas dengan nilai Cronbach's Alpha 0,917 untuk pengetahuan dan 0,925 untuk sikap. Sedangkan checklist untuk diisi 
saat observasi ke responden terkait kepemilikan dan kondisi dengan sarana air bersih, jamban, SPAL, dan sarana pembuangan sampah. Analisis data dilakukan dengan menggunakan uji Chi square.

\section{Hasil Penelitian}

Hasil penelitian yang telah dilakukan dapat dideskripsikan sesuai dengan karakteristik responden yang ada di Desa Air Selumar yaitu meliputi usia kepala keluarga, pendidikan kepala keluarga dan pekerjaan kepala keluarga. Hasil deskriptif dari karakteristik responden dapat dijabarkan dalam tabel berikut ini:

Tabel 1. Distribusi Frekuensi Karakteristik Responden Berdasarkan Usia, Pendidikan dan Pekerjaan Di Desa Air Selumar Kecamatan Sijuk Kabupaten Belitung

\begin{tabular}{lll}
\hline Usia & Frekuensi & Persentase (\%) \\
\hline 21-30Tahun & 8 & 7.9 \\
\hline 31-40 Tahun & 22 & 21.8 \\
\hline 41-50 Tahun & 23 & 22.8 \\
\hline 51-60 Tahun & 20 & 19.8 \\
\hline > 60 Tahun & 28 & 27.7 \\
\hline Pendidikan & Frekuensi & Persentase (\%) \\
\hline S1 & 1 & 1,0 \\
\hline SD & 59 & 58,4 \\
\hline SMP & 17 & 16,8 \\
\hline SMA & 14 & 13,9 \\
\hline Tidak Sekolah & 10 & 9,9 \\
\hline Pekerjaan & Frekuensi & Persentase (\%) \\
\hline Buruh Harian Lepas & 78 & 77,2 \\
\hline Karyawan swasta & 8 & 7,9 \\
\hline Nelayan & 6 & 5,9 \\
\hline Petani & 2 & 2,0 \\
\hline PNS & 1 & 1,0 \\
\hline
\end{tabular}

Tabel 1, diketahui bahwa berdasarkan usia responden paling tinggi yaitu dengan responden berumur $>60$ tahun berjumlah 28 atau $(27,7 \%)$ kepala keluarga, berdasarkan pendidikan responden paling tinggi yaitu responden pendidikan SD berjumlah 59 atau $(58,4 \%)$ kepala keluarga dan berdasarkan pekerjaan responden paling tinggi yaitu buruh harian lepas berjumlah 78 atau $(77,2 \%)$ kepala keluarga.

Hasil analisis univariat berdasarkan data yang di peroleh meliputi data tingkat pengetahuan, sikap, tingkat pendapatan, jumlah anggota kepala keluarga dan kepemilikan fasilitas sanitasi dasar rumah tangga yang dapat dijabarkan pada tabel 2. Tabel 2, diketahui bahwa berdasarkan tingkat pengetahuan kepala keluarga Desa Air Selumar Kecamatan Sijuk Kabupaten Belitung paling tinggi yaitu memiliki pengetahuan tidak baik sebesar 59 atau 58,4\%, sedangkan sikap kepala keluarga Desa Air Selumar Kecamatan Sijuk Kabupaten Belitung paling tinggi yaitu memiliki sikap tidak baik sebesar 67 atau 66,3\%. Tingkat pendapatan kepala keluarga Desa Air Selumar Kecamatan Sijuk Kabupaten Belitung paling banyak yaitu memiliki pendapatan rendah sebesar 61 atau 60,4\%. Mayoritas anggota keluarganya rendah sebesar 78 atau 77,2\% dan berdasarkan kepemilikan fasilitas sanitasi dasar rumah tangga paling tinggi yaitu dengan kepemilikan fasilitas sanitasi dasar rumah tangga tidak lengkap sebesar 62 atau $61.4 \%$. 
Tabel 2. Distribusi Frekuensi Responden Berdasarkan Tingkat Pengetahuan, Sikap, Tingkat Pendapatan dan Jumlah Anggota Di Desa Air Selumar Kecamatan Sijuk Kabupaten Belitung

\begin{tabular}{|c|c|c|c|}
\hline \multicolumn{2}{|l|}{ Variabel } & \multirow{2}{*}{$\begin{array}{c}\text { Frekuensi } \\
59 \\
\end{array}$} & \multirow{2}{*}{$\frac{\text { Persentase }(\%)}{58.4}$} \\
\hline Pengetahuan & Tidak Baik & & \\
\hline & Baik & 42 & 41.6 \\
\hline \multirow[t]{2}{*}{ Sikap } & Tidak Baik & 67 & 66.3 \\
\hline & Baik & 34 & 33.7 \\
\hline \multirow[t]{2}{*}{ Pendapatan } & Rendah & 61 & 60.4 \\
\hline & Tinggi & 40 & 39.6 \\
\hline \multirow[t]{2}{*}{ Aanggota keluarga } & Rendah & 78 & 77.2 \\
\hline & Tinggi & 23 & 22.8 \\
\hline \multirow[t]{2}{*}{ Kepemilikan sanitasi Dasar } & Tidak Lengkap & 62 & 61.4 \\
\hline & Lengkap & 39 & 38.6 \\
\hline
\end{tabular}

Hasil analisis bivariat hubungan antara tingkat pengetahuan, sikap, tingkat pendapatan dan jumlah anggota kepala keluarga dengan kepemilikan fasilitas sanitasi dasar rumah tangga di Desa Air Selumar Kecamatan Sijuk Kabupaten Belitung dijabarkan dalam tabel 3.

Tabel 3. Hubungan Antara Tingkat Pengetahuan, Sikap, Tingkat Pendapatan dan Jumlah Anggota Keluarga Dengan Kepemilikan Fasilitas Sanitasi Dasar Rumah tangga Di Desa Air Selumar Kecamatan Sijuk Kabupaten Belitung

\begin{tabular}{|c|c|c|c|c|c|c|c|}
\hline \multirow{3}{*}{\begin{tabular}{|c|} 
Variabel \\
Tingkat Pengetahuan \\
\end{tabular}} & \multicolumn{4}{|c|}{$\begin{array}{c}\text { Kepemilikan Fasilitas } \\
\text { Sanitasi Dasar Rumah } \\
\text { Tangga }\end{array}$} & \multirow[t]{3}{*}{$\begin{array}{c}\mathbf{P} \\
\text { Value }\end{array}$} & \multirow[t]{3}{*}{ CI 95\% } & \multirow[t]{3}{*}{$\mathbf{R P}$} \\
\hline & \multicolumn{2}{|c|}{$\begin{array}{c}\text { Tidak } \\
\text { Lengkap }\end{array}$} & \multicolumn{2}{|c|}{ Lengkap } & & & \\
\hline & $\mathrm{N}$ & $\%$ & $\mathrm{~N}$ & $\%$ & & & \\
\hline Tidak Baik & 49 & 48,5 & 10 & 9,9 & 0,000 & $1,683-$ & 2,683 \\
\hline Baik & 13 & 12,9 & 29 & 28,7 & & 4,277 & \\
\hline \multicolumn{8}{|l|}{ Sikap } \\
\hline Tidak Baik & 48 & 47,5 & 19 & 18,8 & \multirow[t]{2}{*}{0,005} & $1,133-$ & \multirow[t]{2}{*}{1,740} \\
\hline Baik & 14 & 13,9 & 20 & 19,8 & & 2,672 & \\
\hline \multicolumn{8}{|l|}{ Tingkat Pendapatan } \\
\hline Rendah & 50 & 49,5 & 11 & 10,9 & \multirow[t]{2}{*}{0,000} & 1,678 & \multirow[t]{2}{*}{2,732} \\
\hline Tinggi & 12 & 11,9 & 28 & 27,7 & & 4,450 & \\
\hline \multicolumn{8}{|c|}{ Jumlah anggota keluarga } \\
\hline Rendah & 50 & 49,5 & 11 & 10,9 & \multirow[t]{2}{*}{0,016} & $1,020-$ & \multirow[t]{2}{*}{1,736} \\
\hline Tinggi & 12 & 11,9 & 28 & 27,7 & & 2956 & \\
\hline
\end{tabular}

Tabel 3, menunjukkan bahwa ada hubungan antara tingkat pengetahuan dengan kepemilikan fasilitas sanitasi dasar rumah tangga ( $p$ value $=0,000, C I=1,683-4,277, R P=2,683$ ), ada hubungan antara sikap dengan kepemilikan fasilitas sanitasi dasar rumah tangga ( $p$ value $=0,005, C I=1,133-2,672$, $R P=1,740)$, ada hubungan antara tingkat pendapatan dengan kepemilikan fasilitas sanitasi dasar 
rumah tangga ( $p$ value $=0,000, C I=1,678-4,450, R P=2,732$ ), dan ada hubungan antara jumlah anggota keluarga dengan kepemilikan fasilitas sanitasi dasar rumah tangga ( $p$ value $=0,016, C I=1,020-2956$, $R P=1,736)$.

\section{Pembahasan}

\section{Hubungan Antara Tingkat Pengetahuan dengan Kepemilikan Fasilitas sanitasi Dasar Rumah Tangga}

Hasil penelitian diketahui bahwa responden sebagian besar memiliki pengetahuan yang kurang baik tentang kepemilikan fasilitas sanitasi dasar rumah tangga. Hasil analisis bivariat menyatakan $p$ value yaitu 0,000 yang berarti $p$ value $<0,05$ sehingga dapat disimpulkan terdapat hubungan yang signifikan antara tingkat pengetahuan dengan kepemilikan fasilitas sanitasi dasar rumah tangga di Desa Air Selumar Kecamatan Sijuk Kabupaten Belitung. Selanjutnya berdasarkan nilai Confident Interval (CI) berada diantara 1,683-4,277 dan nilai Ratio Prevalens (RP) yaitu 2,683 maka $>1$ yang artinya merupakan faktor risiko, dapat disimpulkan kepala keluarga yang memiliki tingkat pengetahuan tidak baik beresiko 2,683 kali lebih besar untuk tidak memiliki fasilitas sanitasi dasar rumah tangga dibandingkan dengan kepala keluarga yang memiliki tingkat pengetahuan baik.

Pengetahuan adalah suatu hal yang diketahui seseorang atau responden yang berkaitan dengan sehat dan sakit atau kesehatan. Misalnya tentang sanitasi pelayanan kesehatan dan kesehatan ${ }^{10}$. Tingkat pengetahuan memiliki hubungan dengan kepemilikan fasilitas sanitasi dasar rumah tangga. Sesuai dengan penelitian terdahulu menyatakan bahwa pengetahuan kesehatan berbanding lurus dengan perilaku kesehatan, yang berarti semakin baik pengetahuan seseorang, maka perilakunya akan semakin baik juga, dan sebaliknya jika seseorang tidak baik pengetahuannya, maka perilakunya pun akan kurang baik juga ${ }^{11}$. Penelitian terdahulu menyatakan bahwa semakin tinggi pengetahuan sesorang mengenai fasilitas sanitasi dasar rumah tangga, maka semakin baik pula pemanfaatan fasilitas sanitasi dasar rumah tangga ${ }^{12}$

Teori Green menyatakan bahwa ada tiga faktor yang mempengaruhi perilaku yaitu pengetahuan, sikap keyakinan dan nilai, berkenaan dengan motivasi seseorang bertindak. Faktor pemungkin dan pendorong perilaku adalah fasilitas, sarana atau prasarana yang mendukung perilaku seseorang. Terakhir faktor penguat seperti keluarga, petugas kesehatan dan lain-lain ${ }^{13}$. Oleh karena itu, pengetahuan sangat menentukan sesorang dalam berperilaku. Pengalaman dan penelitian yang telah dilakukan bahwa terbukti tindakan yang didasari oleh pengetahuan akan lebih berpengaruh ${ }^{14}$.

Tingkat pengetahuan responden yang kurang baik dikarenakan banyak hal. Menurut penelitian terdahulu menyatakan bahwa ada beberapa hal yang dapat mempengaruhi tingkat pengetahuan yaitu, tingkat pendidikan, akses akan informasi, pengalaman dan sosial ekonomi ${ }^{15}$. Pada penelitian yang pernah dilakukan bahwa pendidikan sangat mempengaruhi seseorang terhadap pengetahuan yang dimilikinya yang dimana melalui pendidikan sesorang akan dapat mengembangkan potensi dirinya dan memperoleh pengetahuan maupun keterampilan yang dibutuhkan untuk meningkatkan derajat kesehatannya serta keluarganya. Seseorang yang bekerja sebagai PNS akan lebih mudah mendapatkan akses informasi dari pada yang bekerja di desa.

\section{Hubungan Antara Sikap dengan Kepemilikan Fasilitas sanitasi Dasar Rumah Tangga}

Hasil uji bivariat didapatkan hasil nilai $p$ value yaitu 0,005 yang berarti $p$ value $<0,05$ sehingga dapat disimpulkan terdapat hubungan yang signifikan antara sikap dengan kepemilikan fasilitas sanitasi dasar rumah tangga di Desa Air Selumar Kecamatan Sijuk Kabupaten Belitung. Selanjutnya berdasarkan nilai Confident Interval (CI) berada diantara 1,133-2,672 dan nilai Ratio Prevalens (RP) yaitu 1,740 maka $>1$ yang artinya merupakan faktor risiko, dapat disimpulkan kepala 
keluarga yang memiliki sikap tidak baik beresiko 1,740 kali lebih besar untuk tidak memiliki fasilitas sanitasi dasar rumah tangga dibandingkan dengan kepala keluarga yang memiliki sikap baik.

Pernyataan ini didukung oleh penelitian terdahulu yang menyatakan bahwa adanya hubungan sikap dengan kepemilikan fasilitas sanitasi dasar rumah tangga. Sikap merupakan refleksi dari pikiran manusia sehingga pengetahuan masyarkat yang rendah berkontribusi terhadap terbentuknya sikap sesorang. Perilaku sesorang atau masyarkat tentang kesehatan ditentukan oleh sikap seseorang. Semakin buruk sikap seseorang terhadap kepemilikan fasilitas sanitasi asar rumah tangga, maka semakin kecil kemungkinan sesorang memiliki fasilitas sanitasi dasar rumah tangga ${ }^{16}$.

Sikap masyarakat yang buruk tentang kepemilikan fasilitas sanitasi dasar rumah tangga di Desa Air Selumar Kecamatan Sijuk Kabupaten Belitung dipengaruhi oleh keadaan sosial ekonomi. Sebagian besar kepala keluarga bekerja sebagai buruh haruan lepas yang hanya berpenghasilan rendah. waktu mereka di habiskan untuk bekerja sehingga membuat mereka tidak ada waktu untuk mencari informasi tentang fasilitas sanitasi dasar rumah tangga dan membuat mereka tidak peduli dengan keadaan tersebut. Sejalan dengan teori yang ada bahwa adanya sikap positif dan negatif tersebut tergantung dari persepsi masyarkat melalui keuntungan dan kerugian dalam membuat fasilitas sanitasi dasar rumah tangga. Kepala keluarga yang memiliki sikap positif akan membuat fasilitas sanitasi dasar rumah tangga, sedangkan responden dengan sikap baik-baik saja dengan jika tidak memiliki fasilitas sanitasi dasar rumah tangga ${ }^{17}$.

Sikap merupakan suatu raksi berupa pendapat atau penilaian seseorang atau responden terhadap hal yang berkaitan dengan kesehatan, sehat-sakit dan faktor yang berkaitan dengan faktor risiko kesehatan. Salah satu faktor dalam menentukan derajat kesehatan pada masyarakat yakni lingkungan bersih, hal ini akan tercapai apabila seseorang bersikap dan berperilaku yang benar dan baik terhadap lingkungannya. Sikap yang baik terhadap Perilaku Hidup Bersih dan Sehat sangat menentukan tingkat kebersihan sarana sanitasi rumah tinggal, karena semakin baik sikap seseorang dalam menerapkan perilaku hidup bersih dan sehat maka akan semakin tinggi derajat kesehatan ${ }^{18}$.

Dari hasil penelitian ini perlu adanya upaya mendorong masyarakat untuk menerapkan sikap positif kedalam perilaku mereka. Tokoh masyarkat, pemerintah desa serta petugas kesehatan harus membuat kebijakan melalui program-program penyuluhan dan bantuan dana dengan melibatkan masyarakat sebagai objek sasaran sebuah program mulai dari penyusunan hingga pelaksanaan program.

\section{Hubungan Antara Tingkat Pendapatan dengan Kepemilikan Fasilitas sanitasi Dasar Rumah Tangga}

Pendapatan atau penghasilan merupakan uang yang diterima oleh perorangan, perusahaan dan organisasi lainnya dalam bentuk upah, gaji, sewa, bunga, komisi, ongkos, dan laba. Hasil p value yaitu 0,000 yang berarti $\mathrm{p}$ value $<0,05$ sehingga dapat disimpulkan terdapat hubungan yang signifikan antara tingkat pendapatan dengan kepemilikan fasilitas sanitasi dasar rumah tangga di Desa Air Selumar Kecamatan Sijuk Kabupaten Belitung. Selanjutnya berdasarkan nilai Confident Interval (CI) berada diantara 1,678-4,450 dan nilai Ratio Prevalens (RP) yaitu 2,732 maka $>1$ yang artinya merupakan faktor risiko, dapat disimpulkan kepala keluarga yang memiliki tingkat pendapatan rendah beresiko 2,732 kali lebih besar untuk tidak memiliki fasilitas sanitasi dasar rumah tangga dibandingkan dengan kepala keluarga yang memiliki tingkat pendapatan tinggi. Sesuai dengan penelitian yang sebelumnya yang menyatakan bahwa ada hubungan pendapatan dengan kepemilikan fasilitas sanitasi dasar rumah tangga ${ }^{19}$.

Tingkat pendapatan yang rendah kurang berpartisipasi dalam menjaga kesehatan lingkungan, sehingga berpengaruh terhadap kepemilikan fasilitas sanitasi dasar rumah tangga. Tetapi ada juga 
terdapat keluarga dengan pendapatan tinggi tidak memiliki fasilitas sanitasi dasar. Hal ini dapat terjadi karena kurangnya kesadaran tentang pentingnya fasilitas sanitasi dasar membuat mereka kurang peduli untuk memperbaiki status kesehatan keluarganya ${ }^{20}$. Responden dalam penelitian ini saat diwawancarai berpendapat bahwa bahan-bahan untuk membuat fasilitas sanitasi membutuhkan biaya, yang sebagian besar keluarga di Desa Air Selumar tidak mampu/berpenghasilan rendah. Sebagian dari masyarakat sudah sadar akan pentingnya fasilitas sanitasi dasar rumah tangga yang meliputi Sarana air bersih (SGL/SPT/PP/KU/PAH), Jamban (sarana Pembuangan kotoran), Sarana Pembuangan Air Limbah (SPAL) dan Sarana Pembuangan Sampah, namun terkendala akan ekonomi yang lemah sehingga sulit untuk mengikuti anjuran yang di sarankan pemerintah.

Masih banyaknya kelurga di desa Air Selumar yang belum memiliki fasilitas sanitasi dasar rumah tangga yang lengkap, terutama belum adanya fasilitas jamban dikarenakan tidak mampu. Hal ini Dinas Kesehatan Kabupaten Belitung dan Pemerintah Desa sudah membuat program anggaran dana untuk membuat fasilitas sanitasi dasar rumah tangga bagi keluarga yang tidak mampu. Untuk keluarga yang tidak mampu diberikannya bantuan berupa bahan-bahan untuk membuat jamban. Meskipun sudah ada bantuan dari pemerintah, tetap saja masih ada keluarga di Desa yang tidak ada jamban, karena bantuan tersebut tidak diberikan ke seluruh kepala keluarga lantaran terlalu banyak keluarga yang tidak punya jamban.

Hasil penelitian ini sejenis dengan penelitian yang dilakukan oleh penelitian terdahulu yang menyatakan bahwa ada hubungan antara pendapatan dengan kepemilikan jamban keluarga. pendapatan yang di atas rata-rata atau di bawah rata-rata cenderung mempengaruhi partisipasi masyarakat dalam pengadaan fasilitas sanitasi dasar rumah tangga ${ }^{21}$. Begitu juga menurut penelitian terdahulu yang menyatakan bahwa keluarga yang berpenghasilan rendah cenderung tidak memenuhi syarat-syarat sanitasi terbukti beberapa keluarga dengan kondisi rumah yang tidak di lengkapi sarana seperti WC, kamar mandi dan air bersih. Jadi tingkat pendapatan juga menentukan sanitasi lingkungan. semakin tinggi tingkat pendapatan maka akan meningkatkan sanitasi lingkungan ${ }^{22}$.

\section{Hubungan Antara Jumlah Anggota Keluarga dengan Kepemilikan Fasilitas sanitasi Dasar Rumah Tangga}

Hasil $p$ value yaitu 0,016 yang berarti $p$ value $<0,05$ sehingga dapat disimpulkan terdapat hubungan yang signifikan antara jumlah anggota keluarga dengan kepemilikan fasilitas sanitasi dasar rumah tangga di Desa Air Selumar Kecamatan Sijuk Kabupaten Belitung. Selanjutnya berdasarkan nilai Confident Interval (CI) berada diantara 1,020-2956 dan nilai Ratio Prevalens (RP) yaitu 1,736 maka $>1$ yang artinya merupakan faktor risiko, dapat disimpulkan kepala keluarga yang memiliki tingkat pendapatan rendah beresiko 1,736 kali lebih besar untuk tidak memiliki fasilitas sanitasi dasar rumah tangga dibandingkan dengan kepala keluarga yang memiliki jumlah anggota keluarga tinggi. Hal ini diperkirakan karena anggota keluarga sangat mempengaruhi pendapatan keluarga, semakin sedikit anggota keluarga, maka semakin sedikit pengeluaran dan semakin tinggi anggota keluarga, maka semakin tinggi pengeluaran kepala keluarga.

Anggota keluarga adalah semua penghuni yang tinggal dalam satu rumah tangga dan menjadi tanggung jawab kepala keluarga. Struktur keluarga dapat berpengaruh terhadap perkembangan keluarga serta pemanfaatan fasilitas sanitasi dasar rumah tangga. Bila ditinjau dari segi pengeluaran anggota keluarga, bahwa anggota keluarga yang banyak dapat mengakibatkan pengeluaran untuk kebutuhan rumah tangga besar pula, pada umumnya pendapatan keluarga di Desa Air Selumar kurang dari UMR yaitu Rp 3.230.023,66. Jadi dapat disimpulkan bahwa semakin kecil anggota keluarga maka semakin baik pula tingkat kepemilikan fasilitas sanitasi dasar rumah tangga.

Dari sudut pandang ilmu ekonomi, hal ini penting demi menjaga bahwa pokok pembahasan 
ilmu ekonomi akan selalu mengarah kepada demand, supply dan distribusi komoditi, dimana komoditinya adalah pelayanan kesehatan bukan kesehatannya sendiri. Kesehatan tidak dapat diperjual belikan, dalam pengertian bahwa kesehatan itu tidak dapat secara langsung dibeli atau dijual di pasar. Oleh karena itu kesehatan hanya merupakan salah satu ciri komoditi. Kegiatan kesehatan salah satu karakteristik dari pelayanan kesehatan, sarana sanitasi seperti kepemilikan fasilitas sanitasi dasar rumah tangga yaitu sarana air bersih, jamban, saluran pembuangan air limbah dan sarana pembuangan sampah ${ }^{23}$.

Berdasarkan hasil penelitian dan teori yang ada, dapat disimpulkan bahwa jumlah anggota keluarga dengan kepemilikan fasilitas sanitasi dasar rumah tangga menunjukkan ada hubungan yang kuat/tinggi terhadap kepemilikan fasilitas sanitasi dasar rumah tangga. Untuk kepala keluarga yang memiliki anggota yang tinggi, jika dilihat dari tingkat pengetahuan dan pendapatan belum memahami akan pentingnya kepemilikan fasilitas sanitasi dasar rumah tangga. Kepala keluarga yang memiliki anggota keluarga yang lebih dari atau sama dengan empat sangat mempengaruhi pendapatan keluarga, sehingga kepala keluarga tidak mampu untuk mengadakan fasilitas sanitasi dasar rumah tangga.

\section{Kesimpulan}

Terdapat hubungan antara tingkat pengetahuan, sikap, tingkat pendapatan dan jumlah anggota keluarga dengan kepemilikan fasilitas sanitasi dasar rumah tangga di Desa Air Selumar Kecamatan Sijuk Kabupaten Belitung.

\section{Saran}

Disarankan kepada seluruh keluarga yang tinggal di Desa Air Selumar Kecamatan Sijuk Kabupaten Belitung untuk dapat menyadari dan meningkatkan pengelolaan sanitasi rumah tangga melalui pemanfaatan sumber informasi dan berbagai macam pengetahuan serta perlahan-lahan untuk menyediakan fasilitas sanitasi pendukung dalam rumah tangga masing-masing.

\section{Daftar Pustaka}

1. Gruskin K, Geher G. Exploring the Potentiality of Family Resources on Basic Household Sanitation Management in Dense Settlements of Binjai in North Sumatera Province of Indonesia. 2018;12(4):336-347.

2. (WHO) WHO. Water, Sanitation and Hygiene.; 2016. https://www.who.int/gho/phe/water_sanitation/en/.

3. Silva RR, Ribeiro CJN, Moura TR, et al. Basic sanitation: A new indicator for the spread of COVID-19? Trans R Soc Trop Med Hyg. 2021;115(7):832-840. doi:10.1093/trstmh/traa187

4. Heller L, Mota CR, Greco DB. Science of the Total Environment COVID-19 faecal-oral transmission: Are we asking the right questions? Sci Total Environ. 2020;729:138919. https://doi.org/10.1016/j.scitotenv.2020.138919.

5. Virencia K. Menuju RPJMN 2020, Sanitasi and Air Minum Prakondisi Wajib Bagi Permukiman Layak. Jakarta; 2020.

6. Berhe AA, Aregay AD, Abreha AA, et al. Knowledge, Attitude, and Practices on Water, Sanitation, and Hygiene among Rural Residents in Tigray Region, Northern Ethiopia. $J$ Environ Public Health. 2020;2020. doi:10.1155/2020/5460168

7. $\quad$ Kemenkes RI. Profil Kesehatan Indonesia 2018. Jakarta; 2019.

8. Dinkes Provinsi Bangka Belitung. Profil Kesehatan Provinsi Kepulauan Bangka Belitung Tahun 2019. Pangkal Pinang; 2019. 
9. Dinkes Kab.Belitung. Profil Kesehatan Kabupaten Belitung. Belitung; 2020.

10. Avrilinda and Kristiastuti. Pengaruh Pengetahuan dan Sikap Terhadap Perilaku Penjamah Makanan di Kantin SMA Muhammadiyah 2 Surabaya. J Boga. 2016;5(2):1-7.

11. Kamaria C, Darmawan. Faktor-Faktor Yang Mempengaruhi Masyarakat Terhadap Pemanfaatan Jamban Keluarga di Desa Bontotallasa Dusun Makuring Kabupaten Maros. J Kesehat Lingkung. 2013;3(1).

12. Arinto. Faktor-Faktor Yang Mempengaruhi Pemanfaatan jamban Umum Bagi Rumah Tangga Yang Belum Mempunyai Jamban Pribadi. Skripsi. Universitas Sumatera Utara. 2014.

13. Notoatmodjo S. Promosi Kesehatan Dan Perilaku Kesehatan. Jakarta: Reka Cipta; 2013.

14. Azwan F, Dharma S, Nuraini DS. Faktor-Faktor Yang Berhubungan Dengan Rendahnya Kepemilikan Jamban Keluarga dn Personal Hygiene Dengan Kejadian Diare di Desa Sei Musam Kendit Kecamatan Bahorok Kabupaten Langkat Tahun 2014. J Kesehat Lingkung. 2014;2(1):3-9.

15. Lestari T. Kumpulan Teori Untuk Kajian Pustaka Penelitian Kesehatan. 2015:4.

16. Sari RK, Livana PH. Gambaran Faktor-Fakor Yang Berpengaruh Terhadap Cakupan Kepemilikan Jamba Sehat. J Ilm STIKES Kendal. 2018;8(1):56-62.

17. Azwar. Sikap Manusia Teori Dan Pengukurannya. Yogyakarta: Pustaka Pelajar; 2013.

18. Pratiwi PDA, dkk. Hubungan Tingkat Pengetahuan Dan Sikap Ibu Tentang Perilaku Hidup Bersih Dan Sehat (PHBS) Dengan Tingkat Kebersihan Pengelolaan Sarana Sanitasi Di Rumah Shelter Dusun Gempol Jumoyo, Salam, Magelang. J Kesehat Lingkung. 2012;4(1):21-27.

19. Suryani,D. Hendriyadhi, S. Suyitno, and Sunarti, "Kepemilikan Jamban Sehat di Masyarakat Pesisir Desa Binjai Kecamatan Bunguran Barat Kabupaten Natuna," J. Dunia Kesmas, vol. 9, no. 3, pp. 346-354, 2020.

20. Novirty F, Agustian R. Determinan Kepemilikan Jamban Sehat Di Desa Sukomulyo Martapura Palembang. E-Journal.stikesaisyah.ac.id. 2017;2(2):109-114.

21. Darsana IN, Mahayana IMB, Patra IM. Faktor-Faktor Yang Berhubungan Dengan Kepemilikan Jamban Keluarga di Desa Jehem Kecamatan Tembuku Kabupaten Bangli tahun 2013. J Kesehat Lingkung. 2014;4(2):130-131.

22. Rianto S, Nefilinda. Faktor Yang Mempengaruhi Sanitasi Lingkungan Permukiman Di Nagari Aur Begalung Talaok Kecamatan Bayang Kabupaten Pesisir Selatan. J Spasial. 2018;5(2):6371.

23. Ciptoherijanto P, Sutyo B. Ekonomi Kesehatan. Yogyakarta: Muha Medika; 2013. 